\title{
Sodium, Potassium, Calcium, Magnesium, Copper, and Zinc Composition of Erythrocytes in Vitamin $B_{12}$ Deficiency and Iron Deficiency*
}

\author{
Leslie S. Valberg, $\dagger$ John M. Holt, and G. Malcolm Brown with the \\ tech nical assistance of J. Sziver and E. Paulson \\ (From the Division of Hematology and Gastroenterology, Department of Medicine, Queen's \\ University, and the Special Investigation Unit, Kingston General Hospital, \\ Kingston, Ontario, Canada)
}

There have been a number of previous investigations of mineral constituents in the erthyrocytes of patients with iron deficiency and pernicious anemia (1-14), but most of these studies have been restricted to one or two metals. In many of them expression of the mineral composition of the cells has been restricted to the amount per unit volume of packed cells, and in only a few instances has the amount of metal per cell or per unit volume of cell water been given. The published data are widely scattered throughout the literature, and surprisingly few subjects have been studied. Considerable disagreement still exists about the exact composition of the cells in these disorders. In adults with iron deficiency most results suggest that the average amount of sodium, magnesium, copper, and zinc per milliliter of packed red blood cells is not significantly different from normal (1-6), but Pagliardi, Prato, Giangrandi, and Fiorina ( 7 ) have reported recently that copper per milliliter of cells is increased. The concentration of potassium in iron-deficient erythrocytes has been reported to be normal (8), slightly raised $(1,2,9)$, and markedly increased (10) by different workers. In pernicious anemia an increase in erythrocyte zinc has been reported (4, 11), but recently Herring, Leavell, Paixao, and Yoe (3) found normal levels of erythrocyte zinc in this disorder. Magnesium per milliliter of centrifuged cells has been reported to be normal

\footnotetext{
*Submitted for publication December 21, 1964; accepted March 24, 1965.

Supported by a grant from the Medical Research Council of Canada.

† Research Associate, Medical Research Council of Canada. Address requests for reprints to Dr. L. S. Valberg, Etherington Hall, Queen's University, Kingston, Ontario, Canada.
}

(3) and to be increased (12) by different authors. Sodium per milliliter of packed cells has been reported to be raised (13), and potassium and copper have been found to be normal $(2,3,5,6$, 13, 14). Erythrocyte calcium does not appear to have been studied previously in either iron deficiency or in pernicious anemia.

This report concerns a study of the pattern of change in six mineral constituents of the erythrocytes in iron deficiency and in vitamin $\mathrm{B}_{12}$ deficiency. The analytical methods used have taken into consideration differences in cell volume, cell water, cell hemoglobin, and trapped intercellular plasma.

\section{Methods}

The techniques for collection of blood, sample preparation, and analysis of plasma and erythrocytes have been described elsewhere (15-17).

Ten patients with vitamin $B_{12}$ deficiency who ranged in age from 52 to 86 years were selected from cases of pernicious anemia in relapse. The diagnosis was based on the presence of macrocytic anemia, megaloblastic changes in a bone marrow aspirate, impaired absorption of $\mathrm{Co}^{80}-\mathrm{B}_{12}$ that was corrected by the administration of intrinsic factor, and a satisfactory response to treatment with vitamin $\mathrm{B}_{12}$. Eight iron-deficient patients aged 29 to 68 years with anemia due to previous blood loss from either the uterus or the gastrointestinal tract were selected for study on the basis of hypochromic microcytic anemia and the absence of stainable iron in a smear of a bone marrow aspirate. In these subjects correction of certain results for trapped intercellular plasma was made from calibration curves prepared from trapped plasma measurements made by an Evans blue dye dilution technique (16) on the centrifuged erythrocytes of patients with iron deficiency and the patients with pernicious anemia. The mean and range of blood counts in the patients are given in Table I. Compared to the results in a normal control group (17) there was a significant reduction, $p<0.05$, in the mean values for hemoglobin, hematocrit, and red blood cell concentra- 
TABLE I

Blood counts in patients with vitamin $B_{12}$ deficiency and iron deficiency

\begin{tabular}{|c|c|c|c|c|}
\hline & \multicolumn{2}{|c|}{$\begin{array}{l}\text { Vitamin } B_{12} \text {-defi- } \\
\text { cient subjects }\end{array}$} & \multicolumn{2}{|c|}{$\begin{array}{l}\text { Iron-deficient } \\
\text { subjects }\end{array}$} \\
\hline & Mean & Range & Mean & Range \\
\hline $\begin{array}{l}\text { Hemoglobin, } \mathrm{g} / 100 \mathrm{ml} \\
\text { Hematocrit, } \%\end{array}$ & $\begin{array}{l}8.1^{*} \\
24^{*}\end{array}$ & $\begin{array}{l}4.8-11.0 \\
14-31\end{array}$ & $\begin{array}{l}8.7 * \\
28 *\end{array}$ & $\begin{array}{l}4.7-10.8 \\
12-35\end{array}$ \\
\hline $\begin{array}{l}\text { Red blood count, } \\
\text { cells } \times 10^{6} / \mu^{3}\end{array}$ & $2.01 *$ & $1.11-2.79$ & $3.90 *$ & $1.80-4.70$ \\
\hline $\begin{array}{l}\text { Reticulocytes, } \\
\text { cells } \times 10^{8} / \mu^{8}\end{array}$ & 46 & 21-92 & 54 & $39-100$ \\
\hline $\begin{array}{l}\text { Mean corpuscular volume, } \\
\mu^{2} / \text { cell }\end{array}$ & $123 \dagger$ & $109-141$ & $72 *$ & $66-85$ \\
\hline
\end{tabular}

* Mean level decreased significantly, $\mathrm{p}<0.05$, from mean value in control group (17).

+ Mean level increased significantly, $p<0.05$, from mean value in control group (17).

tion in both the iron-deficient and vitamin $B_{12}$-deficient groups. The mean corpuscular hemoglobin concentration was reduced in the iron-deficient group, but the diminution was not marked considering the degree of anemia.

A separate study was made of erythrocyte calcium in ten iron-deficient subjects in which erythrocyte values were corrected for trapped intercellular plasma from individual calibration curves prepared by measuring trapped plasma in each sample with RISA 1 (17). These patients were selected for study on the basis of anemia and the absence of stainable iron in the bone marrow aspirate.

A statistical analysis of the deviation from normal of

1 Abbott Laboratories, Oak Ridge, Tenn. the results in the two disease states was made with Student's $t$ test (18). The equality of the variances was tested by the F test (18), and wherever a significant difference was found between the variances the CoxCochrane correction was applied (19).

\section{Results}

Control subjects. Values for $\mathrm{Na}, \mathrm{K}, \mathrm{Ca}, \mathrm{Mg}$, $\mathrm{Cu}$, and $\mathrm{Zn}$ in the erythrocytes of control subjects have been reported previously (17).

$V$ itamin $B_{12}$ deficiency. The average amount of $\mathrm{Na}, \mathrm{K}, \mathrm{Ca}, \mathrm{Mg}, \mathrm{Cu}$, and $\mathrm{Zn}$ was increased per cell (Table II and Figure 1). The mean increase in $\mathrm{Ca}$ and $\mathrm{Cu}$ was in direct proportion to the increase in cell volume. The average amount of $\mathrm{Na}, \mathrm{Mg}$, and $\mathrm{Zn}$ was increased per cell out of proportion to the increase in cell volume and to the increase in cell water. The levels in five, seven, and ten of the ten patients, respectively, were ouside the normal range. The average levels of both potassium and water per cell and per cubic micron of cell were significantly increased; the amounts per cell were increased above the normal range in all of the patients, and the amounts per cubic micron of cell were increased above the normal range in four of them.

The average total cation concentration per microliter of plasma water was similar in the control subjects and the vitamin $B_{12}$-deficient patients

TABLE II

Chemical composition of erythrocytes in vitamin $B_{12}$ deficiency (mean value $\pm S D$ )

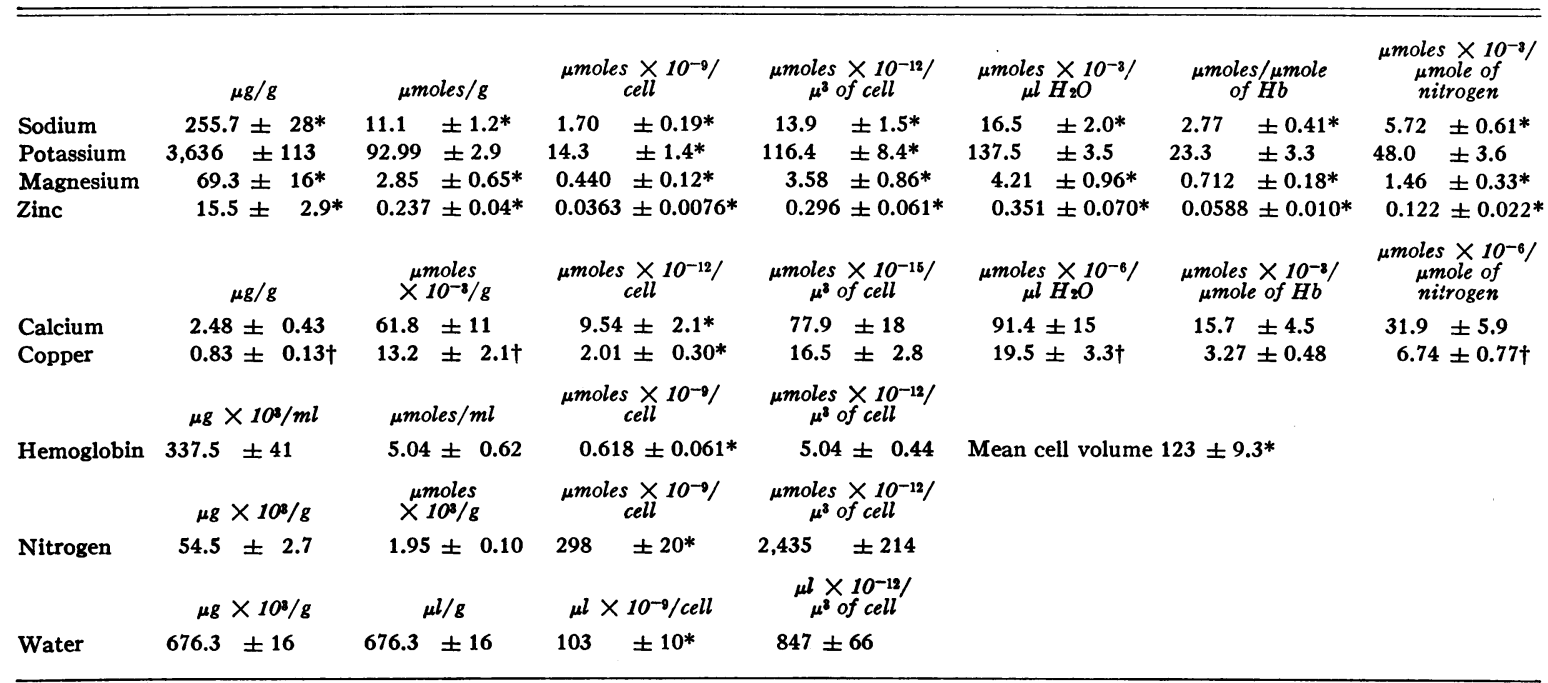

* Mean level increased significantly, $\mathrm{p}<0.05$, from value in control group (17).

+ Mean level decreased significantly, $p<0.05$, from value in control group (17). 


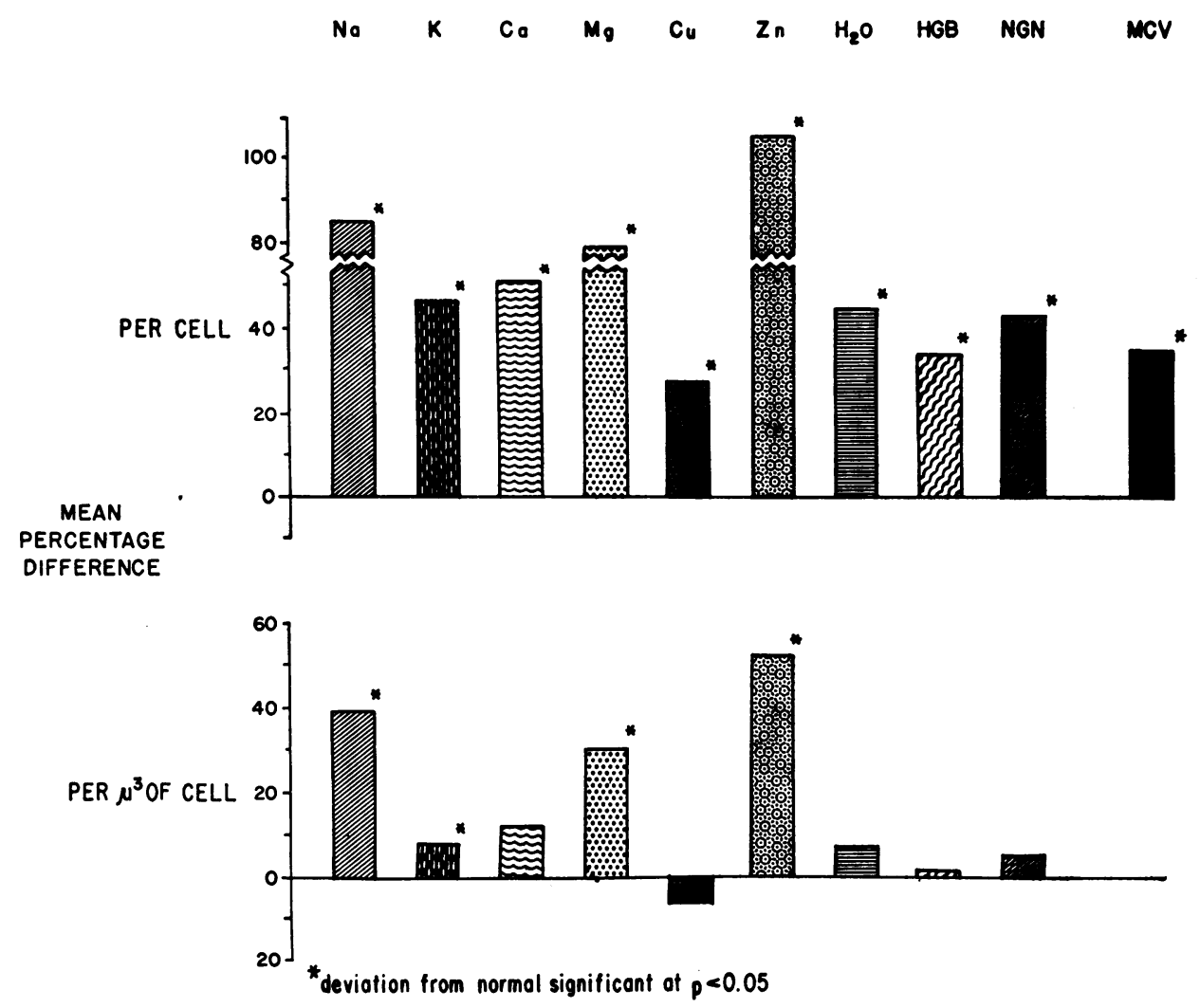

Fig. 1. Percentage deviation of chemical composition of erythrocytes in vitamin B 12 DEFICIENCY FROM RESULTS IN A NORMAL CONTROL GROUP (17). HGB = hemoglobin; NGN = nitrogen; $\mathrm{MCV}=$ mean cell volume.

(Table IV). The average cation level per microliter of erythrocyte water was slightly greater in the cells of patients with vitamin $\mathrm{B}_{12}$ deficiency than in the control subjects due to an increase in the concentration of sodium and magnesium.

Iron deficiency. The average chemical composition of the erythrocytes and the percentage deviation of the results from normal are given in Table III and Figure 2, respectively. As would be expected the mean level of hemoglobin and nitrogen was markedly reduced per cell, but it was only slightly decreased per cubic micron of cell. The average amount of $\mathrm{Na}, \mathrm{Mg}, \mathrm{Cu}$, and $\mathrm{Zn}$ was decreased per cell, but the level per cubic micron of cell and per microliter of water was within normal limits. The average amount of $K$ per cell was decreased, the level per cubic micron of cell, per micromole of hemoglobin, and per micromole of nitrogen was slightly increased, and the concentration per microliter of cell water was normal. The deviation of $\mathrm{K}$ from normal was paralleled by a similar change in cell water. The mean value and range of erythrocyte $\mathrm{Ca}$ was increased per cell, per cubic micron of cell and per microliter of cell water in the iron-deficient subjects. The results in four of the eight patients were above the upper limit of normal, and there was no relationship between the severity of the anemia and the $\mathrm{Ca}$ value.

The average total cation concentration per microliter of plasma water in the iron-deficient subjects was similar to the level in the control group, and the average concentration of cation in the iron-deficient erythrocytes was not significantly different from normal (Table IV).

The hemoglobin concentration, mean cell volume, and erythrocyte calcium values in 11 patients with iron deficiency in whom trapped plasma correction was made with RISA are compared in Table $\mathrm{V}$ to the results in 18 control subjects. The average amount of calcium per cell, per unit volume of cell, per microliter of cell wa- 
TABLE III

Chemical composition of erythrocytes in iron deficiency (mean value $\pm S D$ )

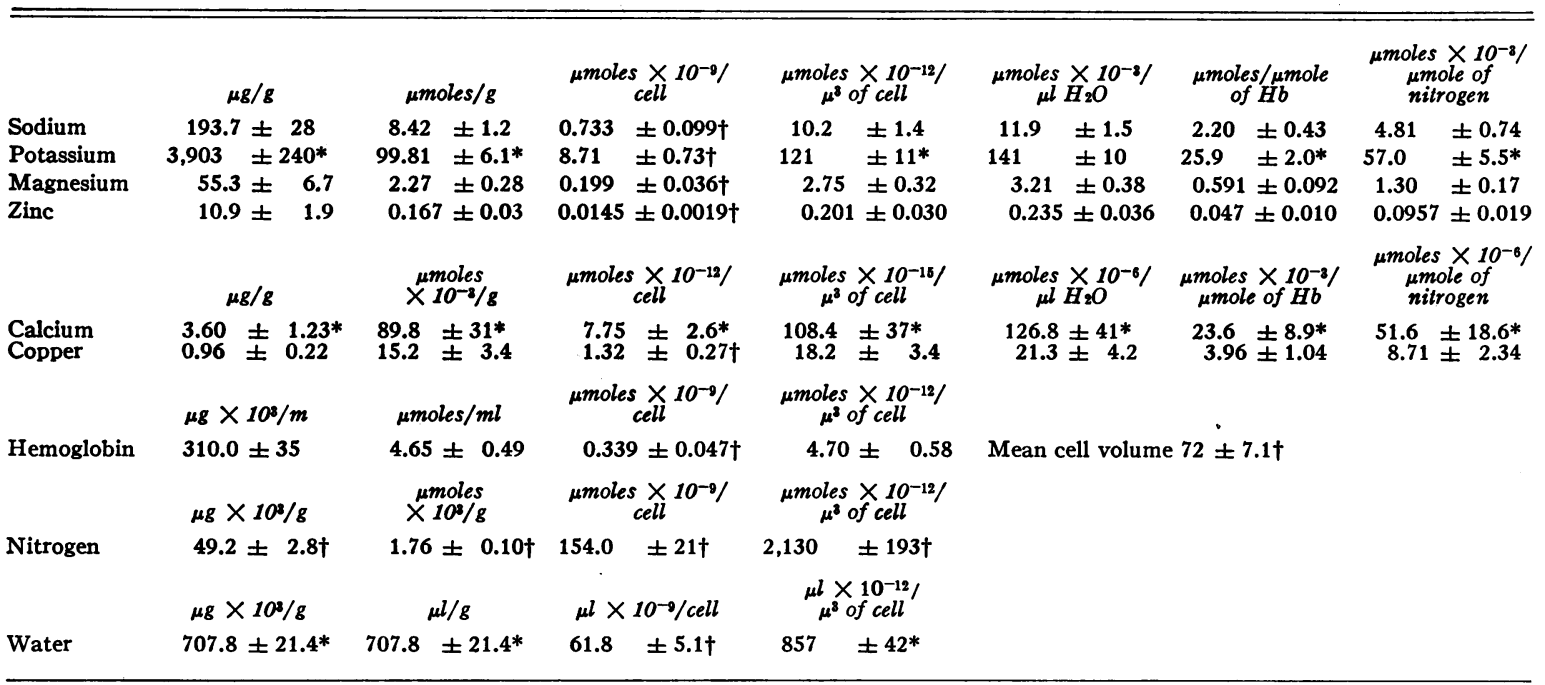

* Mean level increased significantly, $\mathrm{p}<0.05$, from value in control group (17).

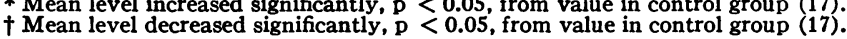

ter, and per micromole of hemoglobin was sig- of calcium in the iron-deficient erythrocytes nificantly increased, and the results in 9 of $11 \mathrm{pa}$ - showed no relationship to the age of the patients, tients were above the normal range. The amount the etiology of the iron deficiency, the degree of

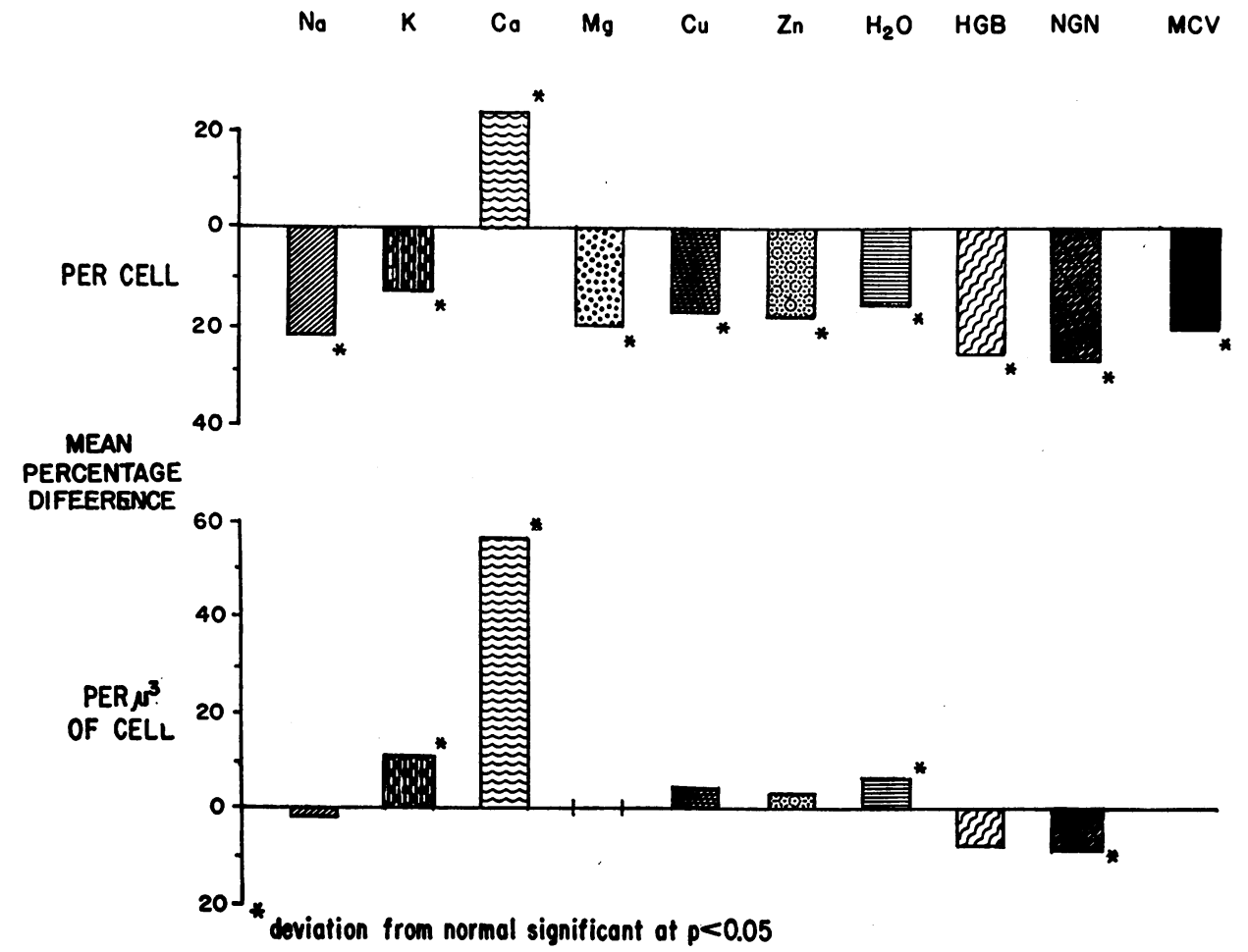

Fig. 2. Percentage deviation of Chemical composition of erythrocytes in IRON Deficiency FROM RESULTS IN A CONTROL GROUP (17). 
anemia, mean cell volume, or to the plasma calcium concentration, which was within the normal range in all of the patients.

\section{Discussion}

The finding of increased erythrocyte zinc in vitamin $B_{12}$ deficiency is in accord with the results of Vallee and Gibson (4) and Talbot and Ross (11), but it contradicts the report of Herring and co-workers that erythrocyte zinc is nor$\mathrm{mal}$ in untreated pernicious anemia. Zinc forms an integral part of carbonic anhydrase, and Vallee, Lewis, Altschule, and Gibson (20) have demonstrated that the increase in zinc in pernicious anemia is paralleled by an increase in the activity of this enzyme. It is of interest that leukocyte zinc is not deviated from normal in this disorder (4).

The finding of increased copper per cell but no significant deviation of copper per cubic micron of cell from normal in the $\mathrm{B}_{12}$-deficient subjects is in agreement with the results of Lahey, Gubler, Cartwright, and Wintrobe (5) (Table VI). Our results also suggest that the average increase in copper per cell is not quite so great as the average increase in water, hemoglobin, or nitrogen per cell
TABLE IV

Total cation concentration of plasma and erythrocytes in vitamin $B_{12}$ deficiency and iron deficiency

\begin{tabular}{|c|c|c|}
\hline & \multicolumn{2}{|c|}{$\begin{array}{l}\text { Average concentration and } \\
\text { standard deviation }\end{array}$} \\
\hline & Plasma & Erythrocytes \\
\hline & \multicolumn{2}{|c|}{$m E q / L$ water } \\
\hline $\begin{array}{r}\text { Vitamin } B_{12} \\
\text { deficiency }\end{array}$ & $162.3 \pm 6.2$ & $162.6 \pm 4.5^{*}$ \\
\hline Iron deficiency & $161.5 \pm 2.6$ & $159.6 \pm 9.5$ \\
\hline
\end{tabular}

* Deviation from control value (17) significant at $\mathrm{p}$ $<0.05$.

and the ratios of copper: water and copper: nitrogen are significantly reduced (Table II).

The explanation for the raised erythrocyte sodium in vitamin $B_{12}$ deficiency is not clear. Shortened erythrocyte survival due to intrinsic abnormality in the cell has been found in pernicious anemia (21), and it is possible that the raised sodium is a reflection of premature senescence of the cells. It is also possible that the raised sodium is secondary to increased permeability of the cell to plasma sodium. Bang and $\emptyset$ rskov (22) have demonstrated that in pernicious anemia there

TABLE V

Calcium levels in erythrocytes of patients with iron deficiency

\begin{tabular}{|c|c|c|c|c|c|c|c|c|c|c|}
\hline \multirow[t]{2}{*}{$\begin{array}{l}\text { Case } \\
\text { no. }\end{array}$} & \multirow[t]{2}{*}{$\underset{\text { years }}{\text { Age }}$} & \multirow[t]{2}{*}{ Sex } & \multirow{2}{*}{\multicolumn{2}{|c|}{$\begin{array}{l}\text { Etiology of iron } \\
\text { deficiency }\end{array}$}} & \multirow{2}{*}{$\begin{array}{c}\begin{array}{c}\text { Hemo- } \\
\text { globin }\end{array} \\
\begin{array}{c}g / 100 \\
m l\end{array}\end{array}$} & \multirow{2}{*}{$\begin{array}{c}\begin{array}{c}\text { Mean cell } \\
\text { volume }\end{array} \\
\mu^{2}\end{array}$} & \multicolumn{4}{|c|}{ Erythrocyte calcium } \\
\hline & & & & & & & $\begin{array}{l}\text { umoles } \\
\times 10^{-12} / \text { cell }\end{array}$ & $\begin{array}{c}\mu \text { moles } \\
\mu^{2} \text { of cell }\end{array}$ & 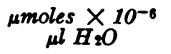 & $\begin{array}{c}\text { amoles } \times 10^{-3} / \\
\mu \text { mole } \mathrm{Hb}\end{array}$ \\
\hline 1 & 68 & $\mathbf{M}$ & \multicolumn{2}{|c|}{ Gastric ulcer } & 8.1 & 89.7 & 5.79 & 64.5 & 78.9 & 13.0 \\
\hline 2 & 36 & $\mathbf{F}$ & \multicolumn{2}{|c|}{ Menorrhagia } & 11.3 & 91.6 & 7.75 & 84.6 & 105.6 & 17.9 \\
\hline 3 & 77 & $\mathbf{F}$ & \multicolumn{2}{|c|}{$\begin{array}{l}\text { Gastrointestinal } \\
\text { bleeding of unknown } \\
\text { origin }\end{array}$} & 11.3 & 92.5 & 6.84 & 73.9 & 92.1 & 15.8 \\
\hline 4 & 65 & $\mathbf{M}$ & \multicolumn{2}{|c|}{ Diverticulosis } & 8.6 & 75.0 & 5.13 & 68.4 & 82.3 & 16.6 \\
\hline 5 & 78 & F & \multicolumn{2}{|c|}{ Partial gastrectomy } & 11.3 & 92.5 & 4.41 & 47.6 & 56.3 & 9.74 \\
\hline 6 & 80 & $\mathbf{F}$ & \multicolumn{2}{|c|}{$\begin{array}{l}\text { Gastrointestinal } \\
\text { bleeding of unknown } \\
\text { origin }\end{array}$} & 10.3 & 94.7 & 6.69 & 70.7 & 86.8 & 14.3 \\
\hline 7 & 40 & $\mathbf{M}$ & \multicolumn{2}{|c|}{$\begin{array}{l}\text { Partial gastrectomy, } \\
\text { stomal ulcer }\end{array}$} & 5.9 & 79.5 & 7.40 & 93.1 & 104.2 & 23.4 \\
\hline 8 & 30 & F & \multicolumn{2}{|c|}{ Menorrhagia } & 9.7 & 87.9 & 7.83 & 89.0 & 110.5 & 18.6 \\
\hline 9 & 83 & $\mathbf{M}$ & \multicolumn{2}{|c|}{ Hiatus hernia } & 8.5 & 70.4 & 4.54 & 64.5 & 81.5 & 15.2 \\
\hline 10 & 80 & $\mathbf{M}$ & \multicolumn{2}{|c|}{ Gastric ulcer } & 9.7 & 88.9 & 5.64 & 63.4 & 80.4 & 12.7 \\
\hline 11 & 60 & $\mathbf{F}$ & \multicolumn{2}{|c|}{ Diverticulosis } & 10.9 & 89.8 & 2.53 & 28.3 & 38.5 & 5.94 \\
\hline \multicolumn{4}{|c|}{$\begin{array}{l}\text { Iron-deficient subjects } \\
18 \text { control subjects }\end{array}$} & $\begin{array}{l}\text { Mean value } \pm S D \\
\text { Mean value } \pm \text { SD } \\
\text { Range }\end{array}$ & & $\begin{array}{l}86.6 \pm 7.8 \\
90.7 \pm 3.5 \\
(83.3-96.2)\end{array}$ & $\begin{array}{l}5.87 \pm 1.64 * \\
3.93 \pm 0.87 \\
(2.44-5.38)\end{array}$ & $\begin{array}{l}68.0 \pm 18.5 * \\
43.2 \pm 9.17 \\
(26.3-55.9)\end{array}$ & $\begin{array}{c}83.4 \pm 4.62 * \\
56.7 \pm 12.2 \\
(34.0-73.1)\end{array}$ & $\begin{array}{c}14.8 \pm 4.62 * \\
7.97 \pm 1.64 \\
(5.12-10.2)\end{array}$ \\
\hline
\end{tabular}

* Deviation from mean value in control group statistically significant at $\mathrm{p}<0.01$. 
TABLE VI

Comparison of mineral composition of erythrocytes in vitamin $B_{12-}$ deficient subjects with values in literature

\begin{tabular}{|c|c|c|c|c|c|}
\hline Element & $\begin{array}{l}\text { No. of } \\
\text { cases }\end{array}$ & $\begin{array}{c}\text { Mean level } \\
\text { deviatior }\end{array}$ & $\begin{array}{l}\text { constituent with pe } \\
\text { om normal in paren }\end{array}$ & $\begin{array}{l}\text { entage } \\
\text { neses }\end{array}$ & References \\
\hline \multirow[t]{2}{*}{ Sodium } & 10 & $\begin{array}{c}\mu g / g^{*} \\
256(+27 \%)\end{array}$ & $\begin{array}{l}\mu g \times 10^{-9} / \text { cell } \\
39.1(+82 \%)\end{array}$ & $\begin{array}{c}\mu g \times 10^{-6} / \mu l \mathrm{H}_{2} \mathrm{O} \\
378(+28 \%)\end{array}$ & \multirow{2}{*}{$\begin{array}{l}\text { Present study compared } \\
\text { with values in a normal } \\
\text { control group (17) } \\
\text { Williams and associates (13) } \\
\text { Maizels (2) }\end{array}$} \\
\hline & $\begin{array}{l}6 \\
3\end{array}$ & $\begin{array}{c}756(+110 \%) \\
293(+12 \%)\end{array}$ & $98.7(+313 \%)$ & $460(+18 \%)$ & \\
\hline Potassium & $\begin{array}{r}10 \\
6 \\
6 \\
4\end{array}$ & $\begin{array}{r}3,636(+0.4 \%) \\
3,966(+7 \%) \\
2,833-3,500(0 \%) \\
3,737(0 \%)\end{array}$ & $\begin{array}{l}558(+45 \%) \\
527(+90 \%)\end{array}$ & $\begin{array}{l}5,376(+1 \%) \\
5,889(+1 \%)\end{array}$ & $\begin{array}{l}\text { Present study } \\
\text { Williams and associates (13) } \\
\text { Bertcher and Meyer (14) } \\
\text { Maizels (2) }\end{array}$ \\
\hline Magnesium & $\begin{array}{r}10 \\
8 \\
6\end{array}$ & $\begin{array}{r}69.3(+22 \%) \\
112(+93 \%) \\
91(+23 \%)\end{array}$ & $10.7(+76 \%)$ & $102(+22 \%)$ & $\begin{array}{l}\text { Present study } \\
\text { Bang and Ørskov (12) } \\
\text { Herring and associates (3) }\end{array}$ \\
\hline Zinc & $\begin{array}{r}10 \\
9 \\
6 \\
8\end{array}$ & $\begin{array}{r}15.5(+42 \%) \\
20.6(+58 \%) \\
8.2(-18 \%) \\
20.8(+76 \%)\end{array}$ & $\begin{array}{l}2.37(+104 \%) \\
2.59(+113 \%)\end{array}$ & $23.0(+43 \%)$ & $\begin{array}{l}\text { Present study } \\
\text { Vallee and Gibson (4) } \\
\text { Herring and associates (3) } \\
\text { Talbot and Ross (11) }\end{array}$ \\
\hline Copper & $\begin{array}{r}10 \\
? \\
6 \\
2\end{array}$ & $\begin{array}{r}0.83(-12 \%) \\
1.25(+14 \%) \\
0.81(0 \%) \\
0.89(-15 \%)\end{array}$ & $\begin{array}{l}0.13(+26 \%) \\
0.126(+25 \%)\end{array}$ & $1.24(-11 \%)$ & $\begin{array}{l}\text { Present study } \\
\text { Gisinger (6) } \\
\text { Herring and associates (3) } \\
\text { Lahey and associates (5) }\end{array}$ \\
\hline
\end{tabular}

${ }^{*}$ Results in the literature expressed as wt/vol of packed cells were converted to wt/wt with 1.095 as the specific gravity of the erythrocytes.

is increased permeability of the erythrocytes to glucose, malonamid, and thiourea, and it is not unreasonable to postulate that permeability to sodium might be increased too. Another possible explanation is a specific defect in the sodium pump due either to an intrinsic defect in the cell or to damage by an extrinsic factor in the plasma. The survival of normal erythrocytes in patients with pernicious anemia is shortened (21), and it may be that inhibition of the sodium pump is brought about by a noxious factor in the plasma.

The finding of an increase in the average amount of magnesium per cell and per cubic micron of cell in vitamin $\mathrm{B}_{12}$ deficiency confirms the earlier observation of Bang and Ørskov (12), but it refutes the recent report of Herring and associates (3) that erythrocyte magnesium is normal in untreated pernicious anemia. The raised erythrocyte magnesium was not associated with abnormality in the plasma magnesium concentration. It is of interest that in vitamin $B_{12}$ deficiency many of the enzymes in the erythrocyte involved in anaerobic glycolysis including phosphoglycerate kinase and pyruvate phosphokinase, which are activated by magnesium ions (23), are increased two or three times greater than one would expect from the increase in cell size $(24,25)$. Despite this, the glucose uptake of the cell has been reported to be decreased $(26,27)$.

In iron deficiency the diminution per cell in the average amount of sodium, magnesium, copper, and zinc was directly proportional to the change in cell volume and cell hemoglobin. The results are in accord with those found by others with one exception (Table VII). The finding of Pagliardi and associates (7) of increased copper per milliliter of erythrocytes in adults with iron deficiency has not been confirmed. Lahey and co-workers (5) have reported increased amounts of copper per cell in 5 of 14 iron-deficient infants, but they found normal levels in adults with iron deficiency. The reason for the difference between erythrocyte copper levels in adults and infants with iron deficiency is not clear.

Erythrocyte calcium was raised in four of the eight iron-deficient subjects in whom trapped plasma correction was made from a composite calibration curve (Table III) and in 9 of 11 cases 
TABLE VII

Comparison of mineral composition of erythrocytes in iron-deficient subjects with values in literature

\begin{tabular}{|c|c|c|c|c|c|}
\hline Element & $\begin{array}{l}\text { No. of } \\
\text { cases }\end{array}$ & $\begin{array}{l}\text { Mean leve } \\
\text { deviatio }\end{array}$ & $\begin{array}{l}\text { constituent with } \\
\text { om normal in pa }\end{array}$ & $\begin{array}{l}\text { ercentage } \\
\text { ntheses }\end{array}$ & References \\
\hline \multirow[t]{2}{*}{ Sodium } & 8 & $\begin{array}{c}\mu g / g^{*} \\
193(-4 \%)\end{array}$ & $\begin{array}{l}\mu g \times 10^{-0} / \text { cell } \\
16.8(-21 \%)\end{array}$ & $\begin{array}{c}\mu g \times 10^{-6} / \mu l \mathrm{H}_{2} \mathrm{O} \\
273(-8 \%)\end{array}$ & \multirow{2}{*}{$\begin{array}{l}\text { Present study compared with values } \\
\text { in a normal control group (17) } \\
\text { Ericksen and associates (1) } \\
\text { Maizels (2) } \\
\text { McCance and Widdowson (9) }\end{array}$} \\
\hline & $\begin{array}{l}3 \dagger \\
8 \\
5\end{array}$ & $\begin{array}{l}315(+8 \%) \\
299(-6 \%)\end{array}$ & $25.3(-21 \%)$ & $\begin{array}{l}344(+6 \%) \\
299(-7 \%)\end{array}$ & \\
\hline Potassium & $\begin{array}{r}8 \\
8 \\
5 \\
2 \\
23 \\
3 \dagger\end{array}$ & $\begin{array}{r}3,903(+8 \%) \\
4,120(+7 \%) \\
4,520(+13 \%) \\
5,593(+84 \%) \\
3,429(-2 \%) \\
4,567(+12 \%)\end{array}$ & $341(-12 \%)$ & $\begin{array}{r}5,518(+4 \%) \\
5,310(0 \%) \\
6,320(+5 \%)\end{array}$ & $\begin{array}{l}\text { Present study } \\
\text { Maizels (2) } \\
\text { McCance and Widdowson (9) } \\
\text { Singer, Hoff, Fisch, and DeGraff (10) } \\
\text { Lans, Stein, and Meyer (8) } \\
\text { Ericksen and associates (1) }\end{array}$ \\
\hline Magnesium & $\begin{array}{l}8 \\
6\end{array}$ & $\begin{array}{l}55(-3 \%) \\
80(+8 \%)\end{array}$ & $4.8(-20 \%)$ & $78.1(-6 \%)$ & $\begin{array}{l}\text { Present study } \\
\text { Herring and associates (3) }\end{array}$ \\
\hline Zinc & $\begin{array}{l}8 \\
1 \\
6\end{array}$ & $\begin{array}{r}10.9(0 \%) \\
11.8(-9 \%) \\
11.7(+17 \%)\end{array}$ & $\begin{array}{l}0.95(-18 \%) \\
1.01(-24 \%)\end{array}$ & $15.4(-4 \%)$ & $\begin{array}{l}\text { Present study } \\
\text { Vallee and Gibson (4) } \\
\text { Herring and associates (3) }\end{array}$ \\
\hline Copper & $\begin{array}{c}8 \\
3 \\
14 \dagger \\
6 \\
? \\
8\end{array}$ & $\begin{array}{r}0.96(+2 \%) \\
1.09(-4 \%) \\
1.52(+32 \%) \\
0.73(-10 \%) \\
1.05(+5 \%) \\
2.95(+140 \%)\end{array}$ & $\begin{array}{l}0.083(-17 \%) \\
0.073(-27 \%) \\
0.091(-9 \%)\end{array}$ & $1.35(-3 \%)$ & $\begin{array}{l}\text { Present study } \\
\text { Lahey and associates (5) } \\
\text { Lahey and associates (5) } \\
\text { Herring and associates (3) } \\
\text { Gisinger (6) } \\
\text { Pagliardi and associates (7) }\end{array}$ \\
\hline
\end{tabular}

* Results in the literature expressed as wt/vol of packed cells were converted to wt/wt with 1.095 as the specific gravity of the erythrocytes.

t Children.

where correction for calcium and trapped intercellular plasma was made with RISA (Table V). The large deviation of calcium values about the mean value in the first iron-deficient group is due to differences in the amount of trapped plasma in the packed cells that were not taken into account when trapped plasma correction was made from a composite calibration curve. The lower mean value and narrower range of results for erythrocyte calcium in the second group in which trapped plasma correction was made with RISA is due to greater accuracy of this method and to the slightly higher value for trapped plasma obtained with RISA in comparison to Evans blue dye, the latter having been used to construct the composite calibration curve (17). The explanation in iron deficiency of the raised erythrocyte calcium and the significance of this finding are not clear. The increase in calcium was not related to the severity of the anemia, the mean corpuscular volume, or the mean corpuscular hemoglobin concentration, nor was it associated with abnor- mality in plasma calcium concentration. In the two iron-deficient patients in whom erythrocyte calcium was normal, one (No. 5, Table V) had just recovered from staphylococcal cellulitis of the face that had been successfully treated with penicillin, and the other (No. 11) subsequently developed polycythemia vera after treatment with iron. It is possible that these associated conditions account for the difference between erythrocyte calcium values in these cases and the other patients with iron deficiency, but a study of a larger number of patients with iron deficiency due to different causes is required to settle this.

Gent, Trounce, and Walser (28) have reported that in vitro the binding of calcium ions by erythrocyte ghosts is affected by magnesium ions, but both plasma and erythrocyte magnesium concentrations were normal in the iron-deficient subjects. Dunham and Glynn (29) have reported that calcium ions in small amounts increase the ATPase activity of erythrocyte ghosts three- to fourfold, but higher levels lead to inhibition. The concen- 
tration of calcium ions required to inhibit ATPase activity in these in vitro studies was ten times greater than the levels found in iron-deficient erythrocytes, and it seems unlikely that the less than twofold increase in calcium concentration in these cells (Table V) would produce inhibition of ATPase activity.

Both Henderson (30) and Maizels (2) have previously reported an increase in the cation concentration per unit volume of erythrocytes in pernicious anemia, but appropriate correction for sodium in trapped intercellular plasma was not made in either of these studies, nor was the concentration of erythrocyte magnesium considered. In the present study a significant increase in the average total cation concentration per liter of erythrocyte water was found in vitamin $B_{12}$ deficiency, but the raised level in iron deficiency was not significantly deviated from normal (Table IV).

\section{Summary}

1. The levels of sodium, potassium, calcium, magnesium, copper, and zinc were determined in the erythrocytes of ten patients with untreated pernicious anemia and eight patients with iron deficiency anemia.

2. In vitamin $B_{12}$ deficiency the average amount of each mineral constituent in the cell was increased. The average amount of sodium, magnesium, and zinc was increased per cubic micron of cell, per microliter of cell water, and per micromole of hemoglobin, but only zinc was raised in all of the subjects. The mean increase in potassium per cell was slightly greater than the mean increase in cell volume, and it was accompanied by a similar increase in cell water. The mean increase in calcium and copper was proportional to the increase in cell volume.

3. In iron deficiency the average amount of sodium, potassium, magnesium, copper, and zinc in the cell was decreased. The diminution in sodium, magnesium, copper, and zinc was proportional to the decrease in cell volume. The decrease in potassium per cell was slightly less than the decrease in cell volume, and it was accompanied by a similar change in cell water.

4. Erythrocyte calcium was increased above the normal range in four of eight patients with iron deficiency in whom analysis on packed cells was corrected for calcium in trapped plasma using a composite calibration curve and in 9 of 11 patients in whom trapped plasma correction was made with $\mathrm{I}^{131}$-labeled serum albumin.

5. The average total cation concentration per liter of erythrocyte water was increased in vitamin $\mathrm{B}_{12}$ deficiency.

\section{Acknowledgments}

We gratefully acknowledge the technical assistance of Mrs. Christina Wainwright, Mrs. Lee Devine, Mrs. Daisy Sykes, and Mr. C. Jones, and the help provided by Mrs. Miriam Benson and Mrs. Eva Gonu.

\section{References}

1. Ericksen, B. N., H. H. Williams, F. C. Hummel, P. Lee, and I. G. Macy. The lipid and mineral distribution of the serum and erythrocytes in the hemolytic and hypochromic anemias of childhood. J. biol. Chem. 1937, 118, 569.

2. Maizels, M. The anion and cation contents of normal and anæmic bloods. Biochem. J. 1936, 30, 821.

3. Herring, W. B., B. S. Leavell, L. M. Paixao, and J. H. Yoe. Trace metals in human plasma and red blood cells. Amer. J. clin. Nutr. 1960, 8, 846.

4. Vallee, B. L., and J. G. Gibson II. The zinc content of whole blood, plasma, leukocytes and erythrocytes in the anemias. Blood 1949, 4, 455.

5. Lahey, M. E., C. J. Gubler, G. E. Cartwright, and M. M. Wintrobe. Studies on copper metabolism. VII. Blood copper in pregnancy and various pathological states. J. clin. Invest. 1953, 32, 329.

6. Gisinger, E. The copper metabolism of the erythrocyte. Wien. klin. Wschr. 1960, 72, 159.

7. Pagliardi, E., V. Prato, E. Giangrandi, and L. Fiorina. Behaviour of the free erythrocyte protoporphyrins and of the erythrocyte copper in iron deficiency anemias. Brit. J. Hæmat. 1959, 5, 217.

8. Lans, H. S., I. F. Stein, Jr., and K. A. Meyer. The relation of serum potassium to erythrocyte potassium in normal subjects and patients with potassium deficiency. Amer. J. med. Sci. 1952, 223, 65.

9. McCance, R. A., and E. M. Widdowson. The effect of development, anæmia and undernutrition on the composition of the erythrocytes. Clin. Sci. 1957, 15, 409.

10. Singer, M. M., H. R. Hoff, S. Fisch, and A. C. DeGraff. Red blood cell potassium. Therapeutic implications. J. Amer. med. Ass. 1964, 187, 24.

11. Talbot, T. R., Jr., and J. F. Ross. The zinc content of plasma and erythrocytes of patients with pernicious anemia, sickle cell anemia, polycythemia vera, leukemia, and neoplastic disease. Lab. Invest. 1960, 9, 174. 
12. Bang, O., and S. Ørskov. The magnesium content of the erythrocytes in pernicious and some other anemias. J. clin. Invest. 1939, 18, 497.

13. Williams, H. H., B. N. Ericksen, S. Bernstein, F. C. Hummel, and I. G. Macy. The lipid and mineral distribution of the serum and erythrocytes in pernicious anemia. Before and after therapy. J. biol. Chem. 1937, 118, 599.

14. Bertcher, R. W., and L. M. Meyer. Erythrocyte potassium levels in pernicious anemia and nontropical sprue. Proc. Soc. exp. Biol. (N. Y.) 1952, 81, 383.

15. Szivek, J., E. J. Gilders, J. M. Holt, and L. S. Valberg. Evaluation of rotating platform technique for the spectrochemical analysis of blood cells. Appl. Spectroscopy 1964, 18, 57.

16. Valberg, L. S., J. M. Holt, and J. Szivek. Determination of calcium, magnesium, copper and zinc in red blood cells by emission spectrometry. Analyt. Chem. 1964, 36, 790.

17. Valberg, L. S., J. M. Holt, E. J. Paulson, and J. Szivek. Spectrochemical analysis of sodium, potassium, calcium, magnesium, copper, and zinc in normal human erythrocytes. J. clin. Invest. 1965, 44, 379.

18. Bailey, N. T. Statistical Methods in Biology. London, English Universities Press, 1959, pp. 47, 50.

19. Edwards, A. L. Statistical Methods for the Behavioural Sciences. New York, Rinehart, 1954, p. 273.

20. Vallee, B. L., H. D. Lewis, M. D. Altschule, and J. G. Gibson II. The relationship between carbonic anhydrase activity and zinc content of eryth- rocytes in normal, in anemic and other pathologic conditions. Blood 1949, 4, 467.

21. Hamilton, H. E., E. L. DeGowin, R. F. Sheets, C. D. Janney, and J. A. Ellis. Studies with inagglutinable erythrocyte counts. VI. Accelerated destruction of normal adult erythrocytes in pernicious anemia; contribution of hemolysis to the oligocythemia. J. clin. Invest. 1954, 33, 191.

22. Bang, O., and S. L. Ørskov. Variations in the permeability of the red cells in man, with particular reference to the conditions obtaining in pernicious anemia. J. clin. Invest. 1937, 16, 279.

23. McIntyre, I. An outline of magnesium metabolism in health and disease-a review. J. chron. Dis. 1963, 16, 201.

24. Bock, H. E., H. D. Waller, G. W. Löhr, and O. Karges. Besonderheiten im Fermentgehalt von Negalocyten. Klin. Wschr. 1958, 36, 151.

25. Vuopio, P. Red cell enzymes in anemia. Scand. J. clin. Lab. Invest. 1963, 15 (suppl. 72), 44.

26. Goldhamer, S. M. Glycolysis in the blood of patients with pernicious anemia. J. clin. Invest. 1933, 12, 583.

27. Prankerd, T. A. J. The Red Cell. Springfield, Ill., Charles C Thomas, 1961, p. 122.

28. Gent, W. L. G., J. R. Trounce, and M. Walser. The binding of calcium ion by the human erythrocyte membrane. Arch. Biochem. 1964, 105, 582.

29. Dunham, E. T., and I. M. Glynn. Adenosinetriphosphatase activity and the active movements of alkali metal ions. J. Physiol. (Lond.) 1961, 156, 274.

30. Henderson, L. J. Blood: A Study in General Physiology. New Haven, Yale University Press, 1928. 